\title{
Trophic ecology of the lobster krill Munida gregaria in San Jorge Gulf, Argentina
}

\author{
Julio H. Vinuesa ${ }^{1}$ \& Martín Varisco ${ }^{2}$ \\ ${ }^{1}$ Centro de Desarrollo Costero, Facultad de Humanidades y Ciencias.Sociales, \\ Universidad Nacional de la Patagonia San Juan Bosco, \\ Consejo Nacional de Investigaciones Científicas y Técnicas \\ ${ }^{2}$ Facultad de Ciencias Naturales, Universidad Nacional de la Patagonia San Juan Bosco \\ Consejo Nacional de Investigaciones Científicas y Técnicas. Campus Universitario \\ Ruta 1 Km 4, P.B. (9000), Comodoro Rivadavia, Chubut, Argentina
}

\begin{abstract}
The "langostilla", Munida gregaria, also called lobster krill or squat lobster, is a very common galatheid crustacean in San Jorge Gulf and around the southern tip of South America. Previous studies have shown that this species plays an important role in the trophic webs wherever it has been studied. In order to determine its natural food sources, we analyzed 10 samples (30-36 individuals each) taken from different sites in San Jorge Gulf. Moreover, stomach analyses were performed on 32 fish species, 4 mollusk species, and 7 crustacean species from the gulf. The lobster krill is primarily a detritivore or surface deposit-feeder and secondarily a predator and/or scavenger. Its main energy sources are particulate organic matter and their associated bacteria, small live organisms on the surface of the sediment layer (ostracods, copepods, foraminifers, other protists), and animal debris. Polychaetes are the main prey of lobster krill in the study area. This dual complementary feeding behavior is common in the studied galatheids, making them a fundamental link between detritus and benthic and demersal top predators. Some species of these predators constitute important fisheries. Different life-cycle stages of the squat lobster were preyed on by 32 of the examined species. However, the spectrum of predators is still incomplete, with other species feeding on larvae and juveniles of the species.
\end{abstract}

Key words: feeding, predators, lobster krill, Munida gregaria, San Jorge Gulf, Patagonia.

\section{Ecología trófica de la langostilla Munida gregaria en el golfo San Jorge, Argentina}

RESUMEN. La langostilla, también llamada bogavante ó langostino de los canales, es un crustáceo galateido de gran abundancia en el Golfo San Jorge y otras áreas del extremo sur de América. Trabajos previos han resaltado la importancia de esta especie en todos los lugares donde ha sido estudiada. Se analizaron 10 muestras de 30 a 36 animales cada una, provenientes de distintos sectores del golfo San Jorge, con el fin de reconocer su alimentación natural. Se revisaron también los estómagos de 32 especies de peces, cuatro especies de moluscos y siete especies de crustáceos del golfo. La langostilla se comporta principalmente como detritívoro o consumidor de depósitos superficiales, y secundariamente, como depredador y/o carroñero. Su fuente principal de energía está dada por materia orgánica particulada y sus bacterias asociadas, organismos vivos pequeños que se encuentran en la capa de sedimento superficial (ostrácodos, copépodos, foraminíferos y otros protistas) y restos de organismos muertos. Su presa principal en el área son los poliquetos. Esta dualidad complementaria en su alimentación es común en los galateidos estudiados y lo convierte en un eslabón fundamental entre el detrito y los depredadores terminales bentónicos y demersales, algunas de cuyas especies integran pesquerías de gran importancia. La langostilla ha sido registrada como presa en 32 de las especies analizadas, en distintas etapas de su vida. Sin embargo, el espectro de depredadores es aún incompleto y existirían otras especies que actuarían sobre larvas y juveniles.

Palabras clave: alimentación, depredadores, langostilla, Munida gregaria, golfo San Jorge, Patagonia.

Corresponding author: Julio H. Vinuesa (jvinuesa@speedy.com.ar, julio.vinuesa@gmail.com) 


\section{INTRODUCTION}

Three anomuran decapod crustaceans of the Family Galatheidae are known to live along the coasts and in the shelf waters of the southwestern Atlantic Ocean: Munida gregaria Fabricius, 1793, M. subrugosa White, 1847, and M. spinosa Henderson, 1855 (Boschi et al., 1992). The first two, considered to be one species in Australia (Williams, 1973, 1980), live in sub-littoral waters generally no deeper than 200 m. M. spinosa, however, is found in deeper waters (100-1000 m deep) (Boschi et al., 1992).

In Argentina and Chile, M. gregaria and M. subrugosa have almost always been considered to be different species due to morphological differences in adult specimens (Retamal, 1981, 2000, Boschi et al., 1992, Arntz et al., 1999; Vinuesa, 2005). Recent studies again propose the existence of one only species, M. gregaria (Pérez-Barros et al., 2005), having two morphotypes or highly differentiated subspecies, with $M$. subrugosa being the morphotypes inhabiting the gulf.

Galatheids fisheries have developed due to the very abundant populations of these organisms. Longhurst (1968) estimated the potential galatheids production in the Pacific Ocean, including the two Pleuroncodes species (P. planipes, P. monodon), to be 30,000 to 300,000 tons per year. In Chile, catches of the squat lobster (P. monodon) ranged from 809 tons per year in 2003 to 1254 tons per year in 2005. Landings of another species in this family, the yellow squat lobster (Cervimunida johni), were recorded at 1,929 and 3,002 tons per year tons in the same respective years (SERNAPESCA, 2006). There is no fishery exploiting the lobsters in San Jorge Gulf, although over 2,000 tons are estimated to be lost per year (CEDEPESCA, 2005).

It is important to study the feeding habits of species within a community, as such studies provide important information for understanding the regulation of the populations in a specific area; feeding habits affect abundance, growth, mortality, and possible migrations. It is also important to collect information on the trophic relationships existing between species that are abundant and/or important fishing resources and the rest of the species living in a given area, as this allows us to infer possible future effects on the populations when fishing pressure is applied to the species in question or those that interact with it.

The squat lobster, Munida gregaria, known as bogavante or langostilla in Argentina and langostino in the Chilean channels, is one of the most abundant decapod crustaceans in the Atlantic Patagonian waters and the Tierra del Fuego Archipelago. Studies carried out in the coastal waters of the Strait of Magellan showed densities of 3 to $27 \mathrm{ind} \cdot \mathrm{m}^{-2}$ (Retamal \& Gorny, 2001). In the Beagle Channel, densities of this species differ according to depth, with 1.03 ind $\cdot \mathrm{m}^{-2}$ at depths of less than $40 \mathrm{~m}$ and $0.27 \mathrm{ind} \cdot \mathrm{m}^{-2}$ at greater depths (Tapella, 2002).

The squat lobster is preyed on by various marine mammals such as whales (Matthews, 1932; Nemoto \& Harrison, 1981), dolphins (Longhurst et al., 1967; Schiavini et al., 1997), sea lions (Rayner, 1935; Rodríguez \& Bahamonde, 1986; Koen Alonso et al., 1998), and the sea otter Lutra felina (Sielfeld, 1990). Other predators include a variety of marine birds including cormorants (Rodríguez \& Bahamonde, 1986) and penguins (Thompson, 1993). However, most of the squat lobster's predators are fish that feed on the lobster during its different life stages (Moreno \& Jara, 1984; Rodríguez \& Bahamonde, 1986; Sánchez \& Prenski, 1996). Mollusks such as Octopus sp. (Bahamonde \& Rodríguez, 1985) and Eledone massya (Ré, 1998), the squid Illex argentinus (Brunetti et al., 1998), and crustaceans such as the crabs Lithodes santolla and Paralomis granulosa (Campodónico \& Hernández, 1983; Comoglio et al., 1989; Balzi, 1999) are also mentioned as squat lobster predators in the literature.

San Jorge Gulf is located between 45 and $47^{\circ} \mathrm{S}$, between $65^{\circ} 40^{\prime} \mathrm{W}$ and the coast. It represents an extremely important area within Argentinean fisheries. It is a rearing and fishing area for hake (Merluccius hubbsi), Patagonian prawn (Pleoticus muelleri), Lithodes santolla, and other important resources such as the elephant fish (Callorhynchus callorhynchus), and the pink cusk-eel (Genypterus blacodes), to name a few. All these species form a multispecific fishery that relies on fleets of highly differentiated fishing vessels, for example coastal or harbour-ria, high sea and mid-sea, and freezer vessels.

The diet of the studied galatheids covers a wide spectrum of feeding habits. Some species (e.g., Pleuroncodes planipes) feed almost exclusively on particulate organic matter (POM) (Aureoles-Gamboa \& Pérez Flores, 1997) whereas others are detritivores (e.g., Munida tenuimana) (Cartés, 1993), opportunistic omnivores (e.g., P. monodon) (Madrid et al., 1997), and even occasionally cannibals, as observed in Munida gregaria off New Zealand (Zeldis, 1985). Galatheids studied in the Beagle Channel showed 
two different, simultaneous feeding behaviors: predation on algae, polychaetes, and crustaceans; and bottom-feeding, consuming POM and organisms associated with the surface sediment layer (Romero et al., 2004).

The main objective of this article is to analyze squat lobster feeding and the diversity of the predators acting on this abundant species, which is an essential component of the demersal-benthic community in San Jorge Gulf.

\section{MATERIALS AND METHODS}

The present work was carried out along the central coast of San Jorge Gulf. Samples were taken between 1998 and 2000 in Caleta Cordova, Comodoro Rivadavia, and Caleta Paula using coastal vessels. Samples for the study of feeding behavior were obtained from freezer and high sea vessels in different sectors of San Jorge Gulf in 2005 and 2006 (Fig. 1). All samples were taken with bottom trawling nets with otters and/or beams; mesh sizes were 40 and $80 \mathrm{~mm}$.

Stomach analyses were performed on ten samples taken in different sectors of the gulf and at different depths (Table 1). Sub-samples of 30-36 specimens of both sexes with carapace lengths (CL) over $10 \mathrm{~mm}$ were selected for the analysis. The CL was measured as in previous studies (Tapella et al., 2002; Romero, 2003; Romero et al., 2004). The repletion index was recorded for each stomach (RI: $0=$ no content; $1=<25 \% ; 2=25-50 \% ; 3=$ $50-75 \% ; 4=>75 \%$ ).
Stomach contents were first observed with a stereomicroscope (20X) to identify the larger items and then under optical microscopes (40x and 100x). The frequency of occurrence of the different food items was calculated, as was the percentage of stomachs containing said item for the total stomachs analyzed in each sample.

Particulate organic matter (POM) has been defined as being composed of mucus from organis$\mathrm{ms}$, amorphous aggregates of previously dissolved organic matter, and complexes of associated microorganisms (Alldredge \& Silver, 1988). Here, nonidentified organic remains (RONI) were taken to be disintegrated and semi-digested tissular and cuticular animal remains that had been incorporated during feeding but that could not be identified.

In order to recognize $M$. gregaria predators, regardless of the squat lobster life stage, catches of diverse organisms from five coastal cruises were analyzed. A total of 124 specimens of 32 fish species, 26 specimens of 4 mollusk species, and 25 specimens of 6 crustacean species were collected. Possible predators were identified on board the fishing vessels. The animals were selected for study when haul catches also included squat lobster; only animals with squat lobster in their stomachs were considered. Large fish were dissected, their stomachs extracted, and the contents analyzed macroscopically in situ. For small fish, the stomachs were removed or entire specimens were fixed in $7-8 \%$ formalin solution in sea water for later analysis. Individuals caught in sport fishing and manually along the coastal shoals and beaches near Comodoro Rivadavia were also considered, including an important number of live crabs caught off the beaches of Rada Tilly (2001-2002).

Table 1. Capture dates, geographic position and depth of tows where samples were obtained.

\begin{tabular}{cclc}
\hline Sample & Date & Geographic position & Depth (m) \\
\hline 1 & Jan-05 & $45^{\circ} 10^{\prime} \mathrm{S}-66^{\circ} 15^{\prime} \mathrm{W}$ & 40 \\
2 & May-05 & $45^{\circ} 25^{\prime} \mathrm{S}-66^{\circ} 45^{\prime} \mathrm{W}$ & $45-50$ \\
3 & Aug-05 & $45^{\circ} 12^{\prime} \mathrm{S}-66^{\circ} 34^{\prime} \mathrm{W}$ & $35-40$ \\
4 & Nov-05 & $45^{\circ} 08^{\prime} \mathrm{S}-66^{\circ} 01^{\prime} \mathrm{W}$ & $40-45$ \\
5 & Aug-00 & $45^{\circ} 56^{\prime} \mathrm{S}-67^{\circ} 15^{\prime} \mathrm{W}$ & 70 \\
6 & Aug-01 & $46^{\circ} 13^{\prime} \mathrm{S}-67^{\circ} 30^{\prime} \mathrm{W}$ & 40 \\
7 & Aug-01 & $46^{\circ} 25^{\prime} \mathrm{S}-66^{\circ} 20^{\prime} \mathrm{W}$ & 90 \\
8 & Oct-01 & $45^{\circ} 10^{\prime} \mathrm{S}-66^{\circ} 20^{\prime} \mathrm{W}$ & $20-30$ \\
9 & May-01 & $45^{\circ} 52^{\prime} \mathrm{S}-67^{\circ} 20^{\prime} \mathrm{W}$ & $50-55$ \\
10 & Jun-00 & $45^{\circ} 48^{\prime} \mathrm{S}-67^{\circ} 08^{\prime} \mathrm{W}$ & 84 \\
\hline
\end{tabular}




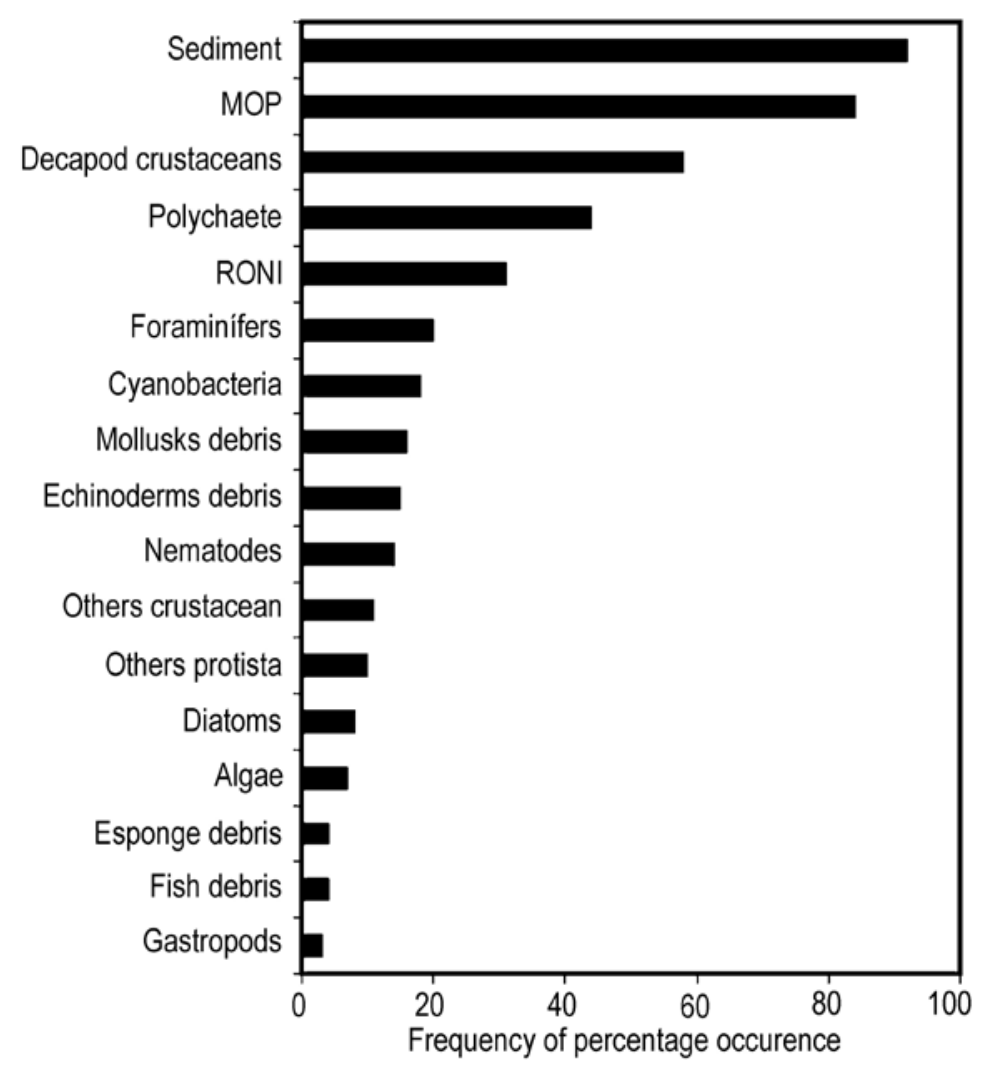

Figure 1. Diet composition of Munida gregaria. MOP: particulate organic matter, RONI: not identified organic debris.

\section{RESULTS}

Altogether, 306 specimens of both sexes were analyzed; $57.2 \%$ were male. The average CL was $16.7 \pm$ $1.39 \mathrm{~mm}$ for females and $21.3 \pm 2.36 \mathrm{~mm}$ for males. The RI varied from 0 to 4 in the studied specimens. Empty stomachs $(\mathrm{RI}=0)$ were found in $9.2 \%$ of specimens $(n=28)$ and complete stomachs $(\mathrm{RI}=4)$ in $5.5 \%$ of them.

Figure 2 indicates the frequency of occurrence of food items found in the stomachs with content. In $84 \%$ of the squat lobster, amorphous POM was found; $92 \%$ had sediments. In all cases, POM represented the highest relative proportion of stomach content in the studied animals.

Decapod crustaceans were the second most important food item (58\%). Patagonian prawn (Pleoticus muelleri) was the most frequent item and bits of squat lobster were also observed, although less frequently. Non-determined peracarid crustacean remains, ostracods, and copepods were also found.

Polychaetes represented an important food item.
Parapodia bits and chaetaes that were isolated or found with tissue remains were observed in $44 \%$ of the squat lobster, indicating that the squat lobster frequently prey on this group.

Non-identified organic remains were also important (31\%); they are believed to come mainly from highly digested crustaceans and polychaetes.

Cyanobacteria of the genera Chlorococcus sp. and Microcoleus sp. and dinoflagellates such as Ceratium sp. and probably Alexandrium sp. were also observed in the stomach contents of the squat lobsters.

Remains of red algae were scarce and consisted largely of Plocamium sp. and other non-determined species not normally found on the bottoms frequented by the species (soft bottoms at depths greater than 30$40 \mathrm{~m}$ ). Diatom frustules corresponded mainly to the centric groups; the genera found were Coscinodiscus sp., Triceratium sp., Pseudo-nitzchia sp. and Chaetoceros sp., although their presence was limited.

Foraminifera were represented by various species, mainly Elphidium sp., Cassidulina sp., Quin- 
queloculina sp., Oolina sp., Eponides sp., Pyrgo sp., and Lagena sp. Remains of other loricate protists, probably thecamoebae and/or tintinnids, were also found.

Scarce remains of sponges were found, as were spicules having 2 to 4 radia and, possibly, spongin fibers. Mollusks were determined to be prey due to the presence of gastropod radulae. Other mollusk remains consisted exclusively of very disintegrated and small shell debris of gastropods and bivalves, probably ingested along with the sediments. The same seems to have happened with echinoderms, as highly disintegrated plates typical of Holothuroidea, spines, and remains of sea urchin and ophiuroid carapaces, as well as fish scales were recorded.

In the predator stomachs, the bright orange color of the squat lobsters facilitated their identification in most cases. However, determining the amount of squat lobsters consumed was not so simple because the remains were usually divided and partially disintegrated or in an advanced state of digestion.

Table 2 shows the predator species and the number of animals analyzed. No squat lobsters were observed in the stomach contents of the following fish: Galeorhinus galeus (tope shark), Myliobatis goodei (southern eagle ray), Parona signata (Parona leatherjacket), Stromateus brasiliensis (butterfish), Seriolella punctata (silver warehou), Percophis brasiliensis (Brazilian flathead), Prionotus sp. (searobin), and Squatina guggenheim (angular angel shark). Two fish of each species were studied, except for the tope shark, for which four specimens were analyzed.

Several of the analyzed species are very rare in the study area because they are distributed in the temperate-warm waters of the Argentina Province. This is the case of the angular angel shark, the southern eagle ray, and the searobin. Their presence in the gulf indicates an important penetration of a temperate-warm water mass.

No remains were found in the crabs Peltarion spinulosum, Libidoclaea granaria, and Platyxanthus patagonicus.

\section{DISCUSSION}

Previous studies indicate that galatheids characteristically feed on surface organic detritus. This strategy is alternated with other feeding methods such as predation and necrophagia (Nicol, 1932; Garm \&
Hoeg, 2000; Madrid et al., 1997; Romero, 2002; Romero et al., 2003).

In San Jorge Gulf, the squat lobster feeds on a reduced variety of benthic organisms. The stomach contents of nearly all the studied animals were mostly POM and sediments (fine sand, silt) with detritus (mollusk shells, skeletal remains of crustaceans and echinoderms) that were at times nearly reduced to the size of coarse sand grains. The squat lobster stomach contents also included sponge spicules, fish scales, and other remains that are were probably part of the surface sediments on the bottoms where these animals live.

In general, few findings indicate that this species acts as an active predator. The presence of algae, for example, indicates the ingestion of algal remains from shallow waters, since there are no algae on the bottoms where the samples were taken. Mollusks are also underrepresented in the diet and it is possible that their frequency is underestimated due to the consistence of their meat. The observed radulae indicate predation on some unidentified gastropod. Although there are various abundant bivalves in the area (e.g., Nuculana sulculata, Nucula puelcha, Kennerleya patagonica; Roux \& Fernández, 1997), no remains were found that indicated predation on these species. Selectivity studies carried out on decapod crustaceans have demonstrated a negative selection on the mollusks, probably due to the species' inability to handle the specimens (Juanes, 1992). In the Beagle Channel, mollusks represented less than $1 \%$ of the relative abundance of the prey (Romero et al., 2004).

Necrophagia is a typical feeding behavior of decapod crustaceans. It is likely that crustaceans probably avoid feeding on some species when they are alive, but do feed on them when they are dead or decomposing. This can be seen in the decapod crustacean fisheries that bait their traps with dead animal remains. Sampling in Nuevo Gulf is being done by baiting the squat lobster traps with hake spines; this method has been very successful (P. Barón, pers. comm.) The presence of Pleoticus muelleri and squat lobster in the stomachs may result from feeding on dead animals that are quite common in the by-catch of coastal and beam-fishing vessels. This could also be the case with fish, although only scales were found and these at very low frequencies.

Only polychaetes and some gastropods seem to be preyed on by the squat lobster, although it is possible that this extends to peracarid crustaceans in some isolated cases. The animals in which these 
prey were found were all males. This could be due to the large size and development of the chelipods, which would give them an advantage over the female squat lobsters. This reveals an important correlation, as females have a higher rate of POM assimilation than males, whereas males assimilate prey organisms better than females (Romero et al., 2006).

The number of species involved in feeding in San Jorge Gulf is lower than that recorded in the Beagle Channel. Here, the species presents the two aforementioned habits: preying on small macroalgae and crustaceans and bottom-feeding, with POM constituting the main energy source for the species (Romero, 2002). This has also been observed in other galatheids, such as Munida tenuimana (Cartés, 1993) and Pleuroncodes planipes (Aureoles-Gamboa \& Pérez Flores, 1997).

In San Jorge Gulf, the squat lobster is basically a bottom-feeder that sweeps the sea floor, scavenging particles with its third pair of maxillipeds. When doing this, they find non-digestible material such as sand, silt, and the hard remains of dead organisms, but also living organisms such as bacteria and protists, the remains of decomposing organisms, and POM that can be assimilated. The squat lobster tears up the dead organisms and eats the meat and organs. Thus, as found in the Beagle Channel, the species represents an important link between POM and many benthic and demersal top predators.

Due to its particular bathymetry, San Jorge Gulf is a very favorable environment for the accumulation of organic substances, principally contributed by organisms that develop their life cycle in this area. In the coastal areas, the bottoms are made up of gravel and sand, and mud predominates in deeper areas, without algae and colonial fauna, which are common in shallow waters with course granulometry (Roux et al., 1995; Fernández et al., 2003). Here, there is an important flux of organic matter to the sea bottom, mainly in the central area, that represents a depositional environment with fine-textured sediments and an accumulation of organic detritus from the water column (Fernández et al., 2005). These elements are taken advantage of by the fauna, which is dominated by filtering bivalves, sea urchins, polychaetes (Roux \& Fernández, 1997) and, temporarily, adult squat lobster. The area in the western sector of the gulf with depths of less than $80 \mathrm{~m}$ is covered with sand and mud with deposits of mixed organic detritus; this area is the most frequented by the species.

The squat lobster also plays a preponderant role in the gulf's ecosystem due to its abundance. Coastal hauls between 40 and $60 \mathrm{~m}$ depth have been recorded in which squat lobster was the main catch, reaching over $300 \mathrm{~kg}$ per haul (G. Giannotta, pers. comm.). Some trawls have resulted in densities of 0.1 to 2.1 lobsters $\cdot \mathrm{m}^{2}$ (Vinuesa, unpublished). Considering that the mesh size of the nets is 4 to $8 \mathrm{~cm}$ in diameter, these figures can be seen to be underestimates of the real amounts.

Its small size, its considerable chemical composition (33.5\% proteins, $11.25 \%$ lipids) (Vinuesa et al., 2002), and its ability to form large agglomerations makes this species a favorite prey of many animals.

Our findings show 24 fish species, four crustacean species, and four mollusk species that prey on the squat lobster. In San Jorge Gulf, nine species were found to feed on the squat lobster: Dyscopyge tschudi, Atlantoraja cychlophora, Cheilodactylus bergi, Patagonotothen ramsayi, Odonthestes smitti, Eurypodius latreillei, Ovalipes trimaculatus, Loligo gahi, and Enteroctopus megalocyathus. These species have not been mentioned in previous studies.

Squat lobster is the main prey year-round of many benthic-demersal fishes also recorded in this study: Genypterus blacodes and G. brasiliensis, Dipturus flavirostris, Psammobatis scobina, Sympterigia bonapartei, Acanthistius brasilianus, Salilota australis, Sebastodes oculatus, Pseudopercis semifasciatus, Xistreuris rasile, and Cottoperca gobio (Sánchez \& Prenski, 1996).

In Chile, nine species mentioned in Table 2 also belong to those preying on the squat lobster: Schroederichthys bivius, Salilota australis, Macruronus magellanicus, Merluccius hubbsi, Cottoperca gobio, Callorhynchus callorhynchus, Dipturus flavirostris, Lithodes santolla, and rays of the genera Psammobatis (Rodríguez \& Bahamonde, 1986). Three cormorant species are also mentioned, as are three species of sea lions Arctocephalus australis, A. gazella, Otaria byronia, and several flounder and other fish in the area, including snoek (Thyrsites atun). The Notothenidae from the Magellanic area deserve a special mention since six of the eight species frequent in the Tierra del Fuego channels have been recorded as predators of the squat lobster (Moreno \& Jara, 1984; Isla \& San Román, 1995). Lithodes santolla has also been mentioned as a predator of the species, both in the Beagle Channel (Comoglio et al., 1989; Tapella et al., 2002) and in San Jorge Gulf (Balzi, 1999), as has Paralomis granulosa in 
Table 2. Registered predators, and total number of analyzed animals and with Munida gregaria in its stomachs.

\begin{tabular}{|c|c|c|c|c|}
\hline Species & Common name & $\begin{array}{c}\text { Total } \\
\text { number }\end{array}$ & $\begin{array}{c}\text { Number of } \\
\text { animals with } \\
\text { lobster krill }\end{array}$ & English name \\
\hline \multicolumn{5}{|l|}{ FISHES } \\
\hline Sympterigia bonapartei & Raya marmolada & 5 & 5 & Smallnose fanskate \\
\hline Discopyge tschudii & Torpedo & 4 & 4 & Electric ray, Apron ray \\
\hline Dipturus chilensis & Raya nariguda & 5 & 5 & $\begin{array}{l}\text { Yellownose skate, Barn- } \\
\text { door skate }\end{array}$ \\
\hline Psammobatis sp. & Raya & 6 & 6 & Sand skate \\
\hline Atlantoraja cychlophora & Raya ojona & 2 & 2 & Eyespot skate \\
\hline Mustelus schmitti & Gatuzo & 5 & 3 & $\begin{array}{l}\text { Narrownose smooth- } \\
\text { hound }\end{array}$ \\
\hline Schroederichthys bivius & Pintarroja & 5 & 5 & $\begin{array}{l}\text { Narrowmouthed } \\
\text { catshark }\end{array}$ \\
\hline Callorhynchus callorhynchus & Pez gallo & 7 & 4 & Elephantfish \\
\hline Engraulis anchoita & Anchoíta & 12 & 3 & Argentine anchovy \\
\hline Merluccius hubbsi & Merluza común & 10 & 4 & Argentine hake \\
\hline Macruronus magellanicus & Merluza de cola & 3 & 1 & $\begin{array}{l}\text { Patagonian grenadier, } \\
\text { longtail hake }\end{array}$ \\
\hline Genypterus blacodes & Abadejo & 5 & 3 & $\begin{array}{l}\text { Pink cusk-eel, Golden } \\
\text { King ling }\end{array}$ \\
\hline Genypterus brasiliensis & Abadejo & 2 & 1 & Kingclip \\
\hline Acanthistius brasilianus & Mero & 3 & 2 & Argentine sea bass \\
\hline Salilota australis & Bacalao del sur & 2 & 2 & $\begin{array}{l}\text { Tadpole codling, } \\
\text { Tadpole mora, } \\
\text { Patagonian cod }\end{array}$ \\
\hline Cottoperca gobio & Cotoperca & 3 & 2 & Thorfish \\
\hline Cheilodactylus bergi & Castañeta & 2 & 1 & Hawkfish \\
\hline Sebastodes oculatus & Cabrilla & 3 & 1 & Scorpionfish \\
\hline Patagonotothen ramsayi & Nototenia & 2 & 1 & No common name \\
\hline Eleginops maclovinus & Róbalo & 6 & 1 & $\begin{array}{l}\text { Antartic rock cod, Nul- } \\
\text { let, Patagonian blenny }\end{array}$ \\
\hline Xystreuris rasile & Lenguado & 3 & 2 & Large-tooth flounder \\
\hline Polyprion americanus & Chernia & 2 & 1 & Wreckfish \\
\hline Pseudopercis semifasciata & Salmón de mar & 3 & 2 & Argentinian sandperch \\
\hline Odonthestes smitti & Pejerrey & 6 & 1 & Silverside \\
\hline \multicolumn{5}{|l|}{ CRUSTACEAN } \\
\hline Eurypodius latreillei & Cangrejo araña & 10 & 1 & Spider crab \\
\hline Leurocyclus tuberculosus & Cangrejo araña & 4 & 1 & Spider crab \\
\hline Ovalipes trimaculatus & Cangrejo nadador & 6 & 1 & Swimming crab \\
\hline Lithodes santolla & Centolla & 5 & 3 & Southern king crab \\
\hline \multicolumn{5}{|l|}{ MOLLUSKS } \\
\hline Illex argentinus & Calamar & 20 & 18 & $\begin{array}{l}\text { Argentine shortfin squid } \\
\text { (FAO) }\end{array}$ \\
\hline Loligo gahi & Calamarete & 4 & 3 & Patagonian squid \\
\hline Enteroctopus megalocyathus & Pulpo colorado & 1 & 1 & Southern octopus \\
\hline Eledone massyae & Pulpo blanco & 1 & 1 & Combed octopus \\
\hline
\end{tabular}


the Beagle Channel (Comoglio et al., 1989).

It is clear that the list of predators indicated in this article is partial, although it includes the extensive study on demersal fishes carried out by Sánchez \& Prenski (1996). Nonetheless, it is very possible that other fish species and sea animals feed on the squat lobster in the waters of San Jorge Gulf. Some fish in which the squat lobster was not found probably feed on it occasionally, as is the case of the southern eagle ray and the angular angel shark, both benthic species. No squat lobsters were found in the pelagic parona leatherjackets, which feed mainly on juvenile fish and zooplankton (Cousseau \& Perrotta, 2000). Although benthic, the Brazilian flathead feeds only on fish (Cousseau \& Perrotta, 2000). Oddly, the squat lobster was not found in the tope shark (it was also not mentioned by Sánchez \& Prenski, 1996), nor was it found in the searobin, which feeds on benthic crustaceans (Cousseau \& Perrotta, 2000).

Birds and mammals were not included in this work; however, many species prey on the squat lobster in other places. In some seasons of the year, it is very common to see seagull guano with disintegrated remains of squat lobster carapaces; the same has been observed in places frequented by cormorants, penguins, and other sea birds. The ever-increasing frequency of the whale Eubalaena australis in the gulf's waters may be due to a search for food, as this species has also been mentioned as a predator of squat lobsters in Patagonian waters (Mathews, 1932; Rayner, 1935).

Many organisms have been observed to feed on adult specimens of $M$. gregaria, but fewer feed on postlarvae and juveniles of the species. Only the Argentine anchovy, (Table 2) and, previously, squid have been found to feed on the larvae (Brunetti et al., 1989). Other fish and planktophagous organisms in the gulf could possibly feed on larvae, for example the sardine Sprattus fueguiensis. Still others could feed on squat lobster larvae and juveniles, for example both parona leatherjackets analyzed herein, the choicy ruff (Seriolella porosa), and other fish and animals.

The species is also found in the Nuevo, San José, and San Matías gulfs, where other benthic-demersal fish, also possible predators, are abundant (e.g., porgies, croakers, sandperchs, flounders, silver sides and other rays). These species are not present in San Jorge Gulf and the more southern temperate-warm waters.

Squat lobster may be easy for the fishing industry to extract if a decision was made to exploit them, as has occurred with similar species in the Pacific Ocean. However, mid-scale and especially smallscale fishing can reduce the stability of the gulf's trophic web. The squat lobster approaches the coast during the breeding season (Vinuesa, 2007) where it forms considerable concentrations, making it easy to catch. It is believed that, if exploitation of this resource begins, it should be done through the by-catch of the current fisheries, which has been estimated to be approximately 2,000 tons (CEDEPESCA, 2005).

\section{ACKNOWLEDGMENTS}

We are grateful for the collaboration of Mr. Gabriel Giannotta and Mr. Luis Badía, skippers of fishing vessels from Caleta Cordova and Comodoro Rivadavia. We also thank Ezequiel Murphy and Ricardo Álvarez of the Secretaría de Pesca, Chubut Province, for samples obtained from large fishing vessels. This paper was funded through grants received from the Argentinean National Committee of Scientific and Technical Research (CONICET) (PIP 02566/99).

\section{REFERENCES}

Alldredge, A.L. \& M.W. Silver. 1988. Characteristics, dynamics, and significance of marine snow. Progr. Oceanogr., 20: 41-82.

Arntz, W.E., M. Gorny, R. Soto, M.A. Lardies, M.A. Retamal \& I. Wehrtmann. 1999. Species composition and distribution of decapod crustaceans in the waters off Patagonia and Tierra del Fuego, South America. In: W.E. Arntz \& C. Ríos (eds.). Magellan-Antarctic. Ecosystems that drifted apart. Sci. Mar., 63(Supl. 1): 303-314.

Aurioles-Gamboa, D. \& R. Pérez-Flores. 1997. Seasonal and bathymetric changes in feeding habits of the benthic red crab Pleuroncodes planipes (Decapoda, Anomura, Galatheidae) off the Pacific coast of Baja California Sur, Mexico. Crustaceana, 70: 272-287.

Bahamonde, R. \& L. Rodríguez. 1985. Explotación del recurso langostino de las aguas interiores, Regiones XI y XII - Prefactibilidad. Inst. Fom. Pesq. Santiago, Chile: 239 pp.

Balzi, P.P. 1999. Los hábitos alimenticios de la centolla, Lithodes santolla (Molina) del golfo San Jorge. Natur. Patag., Cs. Biol., 5: 67-87.

Boschi, E.E., K. Fischbach \& M.I. Iorio. 1992. Ca- 
tálogo ilustrado de los crustáceos estomatópodos y decápodos marinos de Argentina. Frente Marítimo, 10: 7-94.

Brunetti, N.E., M.L. Ivanovic \& B. Elena. 1998. Calamares omastréfidos (Cephalopoda, Ommastrephidae). In: E.E. Boschi (ed.). El Mar Argentino y sus recursos pesqueros. Tomo 2. Los moluscos de interés pesquero. Cultivos y estrategias reproductivas de bivalvos y equinoideos. Instituto Nacional de Investigación y Desarrollo Pesquero, Mar del Plata, pp. 37-68.

Campodónico, I. \& M.B. Hernández. 1983. Estado actual de la pesquería de centolla (Lithodes antarctica) en la Región de Magallanes. In: P. Arana (ed.). Análisis de pesquerías chilenas. Escuela de Ciencias del Mar, PUCV, Valparaíso, pp. 55-76.

Cartés, J.E. 1993. Diets of two deep-sea decapods: Nematocarcinus exilis (Caridea: Nematocarcinidae) and Munida tenuimana (Anomura: Galatheidae) on the western Mediterranean slope. Ophelia, 37: 213-229.

Centro Defensa y Pesca Sustentable (CEDEPESCA). 2005. http://www.cedepesca.org.ar/noticias/descartes_2004.html. Revisado: 10 de noviembre de 2005.

Comoglio, L.I., J.H. Vinuesa \& G.A. Lovrich. 1989. Feeding habits of southern king crab, Lithodes santolla (Molina), and the false king crab, Paralomis granulosa Jacquinot, in the Beagle Channel. Proc. Int. Symp. King \& Tanner crabs. Alaska Sea Grant Coll. Prog. Rep., 90-04: 315- 325.

Cousseau, M.B. \& R.G. Perrotta. 2000. Peces marinos de Argentina: Biología, distribución, pesca. Instituto Nacional de Investigación y Desarrollo Pesquero, Mar del Plata, 167 pp.

Fernández, M., J.I. Carreto, J. Mora \& A. Roux. 2005. Physico-chemical characterization of the benthic environment of the golfo San Jorge, Argentina. J. Mar. Biol. Ass. U.K., 85: 1317-1328.

Fernández, M., A. Roux, E. Fernández, J. Caló, A. Marcos \& H. Aldacur. 2003. Grain-size analysis of surficial sediments from Golfo San Jorge, Argentina. J. Mar. Biol. Ass. U.K., 83: 1193-1197.

Garm, A. \& J.T. Hoeg. 2000. Functional mouthpart morphology of the squat lobster Munida sarsi, with comparison to other anomurans. Mar. Biol., 137: 123-138.

Isla, M.S. \& N. San Román, 1995. Alimentación de Eleginops maclovinus (Pisces, Nototheniidae) en el canal Beagle, Argentina. Natur. Patag., Cs. Biol., 3: $107-127$.

Juanes, F. 1992. Why do decapod crustaceans prefer small-sized molluscan prey? Mar. Ecol. Prog. Ser., 87: 239-242.

Kato, S. 1974. Development of the pelagic red crab (Galatheidae, Pleuroncodes planipes) fishery in the Eastern Pacific Ocean. Mar. Fish. Rev., 36(10): 1-9.

Koen-Alonso, M., E.A. Crespo, N.A. García, S.N. Pedraza \& M.A. Coscarella. 1998. Diet of dusky dolphins, Lagenorhynchus obscurus in waters off Patagonia, Argentina. US. Fish. Bull., 96: 366374.

Longhurst, A.R. 1968. The biology of mass occurrences of galatheid crustaceans and their utilization as a fisheries resource. In: M.N. Mistakidis (ed.). Actas de la Conferencia Científica Mundial sobre la Biología y Cultivo de Camarones y Gambas. FAO, Fish. Rep., 57: 95-110.

Longhurst, A.R., C.J. Lorenzen \& W.H. Thomas. 1967. The role of pelagic crabs in the grazing of phytoplankton off Baja California. Ecology, 48: 190-200.

Lovrich, G.A., M.A. Casalinuovo, C. Cárcamo \& R. Pierotti. 1998. Las langostillas Munida subrugosa y $M$.gregaria (Decapoda, Anomura) como potencial recurso económico patagónico. Natur. Patag., Cs.Biol.,: 89-92.

Madrid, J.A., R. Roa, M.J. Baltasar \& V.A. Gallardo. 1997. Dieta natural del langostino colorado (Pleuroncodes monodon) del lado norte y sur del cañón del río Bío Bío. Taller Internacional "Investigaciones en Biología Marina en el área de Magallanes en relación con la Antártida". Punta Arenas, Chile.

Matthews, L.H. 1932. Lobster-krill, anomuran Crustacea that are the food of whales. Discovery Rep., 5: 467-484.

Moreno, C. \& F. Jara. 1984. Ecological studies on fish fauna associated with Macrocystis pyrifera belts in the south of Fueguian Islands, Chile. Mar. Ecol. Progr. Ser., 15: 99-107.

Nemoto, T. \& G. Harrison. 1981. High latitude ecosystems. In: A.R. Longhurst (ed.). Analysis of marine ecosystems. Academic Press, New York, pp. 95-126.

Nicol, E.A.T. 1932. The feeding habits of the Galatheidae. J. Mar. Biol. Ass. U.K., 18: 87-106.

Pérez-Barros, P., M.E. D’Amato \& G.A. Lovrich. 2005. Munida gregaria vs. Munida subrugosa (Decapoda: Anomura): the beginning of the end of two different species? Ber. Polarforsch. Meeresforsch., 507: 172-174.

Rayner, G.W. 1935. The Falkland species of the crustacean genus Munida. Discovery Rep., 10: 211-245. 
Rè, M.E. 1998. Pulpos octopódidos. In: E.E. Boschi (ed.). El Mar Argentino y sus recursos pesqueros. Tomo 2. Los moluscos de interés pesquero. Cultivos y estrategias reproductivas de bivalvos y equinoideos. Instituto Nacional de Investigación y Desarrollo Pesquero, Mar del Plata, Argentina, pp. 69-98.

Retamal, M.A. 1981. Catálogo ilustrado de los Crustáceos Decápodos de Chile. Gayana, 44: 1-110.

Retamal, M.A. 2000. (CD:ROM). Decápodos de Chile. ETI-Universidad de Concepción. Springer-Verlag, Berlin.

Retamal, M.A. \& M. Gorny. 2001. Decápodos de los fiordos de Chile (Cimar-Fiordo 3). Cienc. Tecnol. Mar, 24: 91-97.

Rodríguez, L. \& R. Bahamonde. 1986. Contribución al conocimiento de Munida subrugosa (White, 1847) en la XII Región, Chile. In: P. Arana (ed.). La Pesca en Chile, Escuela de Ciencias del Mar, PUCV, Valparaíso, pp. 283-296.

Romero, M.C. 2003. Hábitos alimentarios y bioenergética de la langostilla Munida subrugosa (Crustacea, Decapoda) del Canal Beagle, Tierra del Fuego, Argentina. Tesis Doctoral. Universidad Nacional de Córdoba, Argentina, 215 pp.

Romero, M.C., G.A. Lovrich, F. Tapella \& S. Thatje. 2004. Feeding ecology of the crab Munida subrugosa (Decapoda: Anomura: Galatheidae) in the Beagle Channel, Argentina. J. Mar. Biol. Ass. U.K., 84: 359-365.

Romero, M.C., F. Vanella, F. Tapella \& G.A. Lovrich. 2006. Assimilation and oxygen uptake associated with two different feeding habits of Munida gregaria (= M. subrugosa) (Crustacea, Decapoda). J. Exp. Mar. Biol. Ecol., 333: 40-48.

Roux, A. \& M. Fernández. 1997. Caracterización de los fondos de pesca del langostino patagónico Pleoticus muelleri en el Golfo San Jorge y litoral de la provincia de Chubut, Argentina. Inf. Téc. INIDEP, Mar del Plata, 13: 1-28.

Roux, A., M. Fernández \& C. Bremec. 1995. Estudio preliminar de las comunidades bentónicas de los fondos de pesca del golfo San Jorge (Argentina). Cienc. Mar., 21(2): 295-310.

Sánchez, F. \& L.B. Prenski. 1996. Ecología trófica de peces demersales en el golfo San Jorge. Rev. Invest. Des. Pesq., Mar del Plata, 10: 57-71.

Schiavini,A.C.M., R.N.P. Goodall, A.K. Lescrauwaet \& M. Koen-Alonso. 1997. Food habits of the peale's dolphin, Lagenorhynchus australis: review and new information. Rep. Int. Whal. Comm., 47: 827-833.

Servicio Nacional de Pesca (SERNAPESCA). 2006. http://www.sernapesca.cl . Revised: 23 January 2007.

Sielfeld, K. 1990. Dieta del chungungo Lutra felina (Molina, 1782) (Mustelidae, Carnivora) en Chile Austral. Rev. Invest. Cient. Tecnol., Ser. Cs. Mar, 1: 23-29.

Tapella, F. 2002. Reproducción, crecimiento, distribución y abundancia de la langostilla Munida subrugo$s a$ (Anomura: Galatheidae) del Canal Beagle, Tierra del Fuego, Argentina. Tesis Doctoral, Universidad Nacional de Córdoba, Argentina, 154 pp.

Tapella, F., M.C. Romero, G.A. Lovrich \& A. Chizzini. 2002. Life history of the galatheid crab Munida subrugosa in subantarctic waters of the Beagle Channel, Argentina, pp. 115-134. In: A.J. Paul, E.G. Dawe, R. Elner, G.S. Jamieson, G.H. Kruse, R.S. Otto, B. Sainte-Marie, T.C. Shirley \& D. Woodby (eds.). Crabs in cold waters regions: biology, management, and economics. University of Alaska Sea Grant, AK-SG-02-01, Fairbanks, 876 pp.

Thompson, K.R. 1993. Variation in Magellan penguin Spheniscus magellanicus diet in the Falkland Islands. Mar. Ornithol., 21: 57-67.

Vinuesa, J.H. 2005. Distribución de crustáceos decápodos y estomatópodos del Golfo San Jorge, Argentina. Rev. Biol. Mar. Oceanog., 40(1): 7-21.

Vinuesa, J.H. 2007. Reproduction of the squat lobster Munida gregaria (Decapoda: Galatheidae) in San Jorge Gulf, south-west Atlantic Ocean. J. Crust. Biol., 27: 437-444.

Vinuesa, J.H., M. Galdi, G.A. Lovrich, M. López Sardi, M. Figgini, A. Milani \& S.E. Labal. 2002. Composición bioquímica estacional de la langostilla Munida subrugosa (Crustacea, Decapoda, Galatheidae) en aguas patagónico-fueguinas. Informe final, Universidad Argentina John F. Kennedy, Buenos Aires: 14 pp.

Williams, B.G. 1973. The effect of the environment on the morphology of Munida gregaria (Fabricius). Crustaceana, 24: 197-210.

Williams, B.G. 1980. The pelagic and benthic phases of post-metamorphic Munida gregaria (Fabricius) (Decapoda, Anomura). J. Exp. Mar. Biol. Ecol., 42: 125-141.

Zeldis, J.R. 1985. Ecology of Munida gregaria (Decapoda, Anomura): distribution and abundance, population dynamics and fisheries. Mar. Ecol. Prog. Ser., 22: 77-99. 